\title{
SARS-CoV-2: Micronutrient Optimization in Supporting Host Immunocompetence
}

\section{Melanie M. Stipp}

Department of Anesthesia, Critical Care, and Pain Medicine, Massachusetts General Hospital, Boston, Massachusetts, USA.

Corresponding author: Melanie M. Stipp, Department of Anesthesia, Critical Care, and Pain Medicine, Massachusetts General Hospital, Boston, Massachusetts, USA.

\section{Received date: March 18, 2020; Accepted date: April 20, 2020; Published date: April 27,2020}

Citation: Melanie M. Stipp. (2020) SARS-CoV-2: Micronutrient Optimization in Supporting Host Immunocompetence. International Journal of Clinical Case Reports and Reviews. 2(2); DOI:10.31579/2690-4861/024

Copyright: (C) 2020 Melanie M. Stipp, This is an open access article distributed under the Creative Commons Attribution License, which permits unrestricted use, distribution, and reproduction in any medium, provided the original work is properly cited

\section{Abstract}

The novel 2019 coronavirus (SARS-CoV-2) has become an international pandemic. The lack of targeted treatment for SARS-CoV-2 has necessitated the need to evaluate all potential modalities to enhance host immune response. This article reviews the role essential micronutrients play in the risk reduction and treatment of COVID-19. While literature supporting the risk and severity reduction of COVID-19 infections through exogenous supplementation is limited, micronutrient optimization is essential in maintaining host immunocompetence, and deficits may critically impair host defense. The immune supportive mechanisms and physiologic effects of various micronutrients are multifaceted, including the reduction of viral replication, inhibition of polymerase function, augmentation of innate and acquired immune responses, enhancement of anti-inflammatory immune responses, and the reduction of pro-inflammatory responses.

Keywords: COVID-19; immunocompetence; micronutrients; SARS-CoV-2; coronavirus

\section{Host Immune Response}

Micronutrient optimization is critical in maintaining host immunocompetence [4]. Micronutrient deficiencies may predispose the host to viral infection acquisition [4]. Severe cases of SARS-CoV-2 can trigger an uncontrolled inflammatory immune response characterized by lymphopenia, reduced natural killer cells, CD4+, CD8+, T lymphocytes, B lymphocytes, basophils, monocytes, and eosinophils [68]. SARS-CoV2 induced cytokine storm triggers the excessive production of proinflammatory cytokines [68]. Clinical laboratory findings include lymphopenia, elevated CRP, elevated LDH, elevated D-dimer and increased ferritin levels [68]. Cytokine storm precipitates neutrophil and macrophage sequestration, infiltration, pulmonary hyaline membrane formation and diffuse alveolar wall thickening [68]. Subsequently, multiple organ dysfunction may ensue [68].

The immune system response consists of innate and adaptive immunity ${ }^{4}$. Innate immunity includes physiological barrier mechanisms of the respiratory and GI tract, and general non-specific immune responses such as inflammation. This includes leukocyte activity (phagocytes, macrophages, mast cells, neutrophils, eosinophils, natural killer cells and dendritic cells) and complement system activity (opsonisation, cell lysis, agglutination, chemotaxis) [4].

Adaptive, acquired immune responses are antigen-specific, consisting of $\mathrm{B}$ and $\mathrm{T}$ lymphocyte responses [4]. B lymphocytes contribute to the humoral immune response, are highly specific, and bind directly to antigens [4]. T lymphocytes contribute to the cellular-mediated immune response through the expression of $\mathrm{T}$ cell receptors, and CD4+ or CD8+ cells, that recognize antigens bound to class I or II major histocompatibility complexes (MHC) [4].

\section{Vitamin D (1,25-dihydroxyvitamin $\left.\mathrm{D}_{3}\right)$}

Vitamin D (1,25-dihydroxyvitamin $\left.\mathrm{D}_{3}\right)$ reduces the risk of host viral respiratory infection acquisition [1,5-13] 1,25-dihydroxyvitamin $\mathrm{D}_{3}$ can be acquired exogenously or endogenously through the synthesis of steroid hormone, cholecalciferol, when the host is exposed to ultraviolet light $[36,44,47]$ Physiologically, vitamin $\mathrm{D}_{3}$ undergoes hepatic conversion to $25(\mathrm{OH}) \mathrm{D}$ with subsequent renal conversion to its active form, 1,25 dihydroxyvitamin $\mathrm{D}_{3}(1,25(\mathrm{OH}) 2 \mathrm{D}){ }^{1}$. This hormonal metabolite, also known as calcitrol, directly targets genome sequences, inducing genetic and epigenetic transcription modifications [1].

1,25-dihydroxyvitamin $\mathrm{D}_{3}$ functions to promote bone mineralization by regulating serum levels of phosphorus and calcium [36]. Increased levels of serum 1,25-dihydroxyvitamin $\mathrm{D}_{3}$ provides enhanced innate immunity barrier support through the maintenance of gap, tight and adherens junctions [13]. 1,25-dihydroxyvitamin $\mathrm{D}_{3}$ reduces pro-inflammatory cytokines TNF- $\alpha$ and INF- $\gamma$ and increase anti-inflammatory cytokine expression [12,14,15]. 1,25-dihydroxyvitamin $\mathrm{D}_{3}$ elicits antimicrobial peptides, cathelicidins and defensins, which are found to reduce the rate of viral replication and reducing pro-inflammatory cytokine concentrations [1,21]. Observational studies suggest a serum 1,25- 
dihydroxyvitamin $\mathrm{D}_{3}$ therapeutic goal of $\geq 40-60 \mathrm{ng} / \mathrm{mL}(100-150$ $\mathrm{nmol} / \mathrm{L}$ ) in the reduction of hospital-acquired viral infections 16-18].

Supra-therapeutic dosages of 1,25-dihydroxyvitamin $\mathrm{D}_{3}$ have been shown to reduce the duration of hospitalization in ventilated critical care patients from a hospital stay of $36(\mathrm{SD}=19)$ to a duration of $18(\mathrm{SD}=11)$ days in patients receiving treatments of 500,000 IU 1,25-dihydroxyvitamin $\mathrm{D}_{3}$ [19]. Moreover, 1,25-dihydroxyvitamin $\mathrm{D}_{3}$ has been clinically shown to increase levels of hemoglobin, enhance the metabolism of iron, and improve host oxygen carrying capacity [19,20].

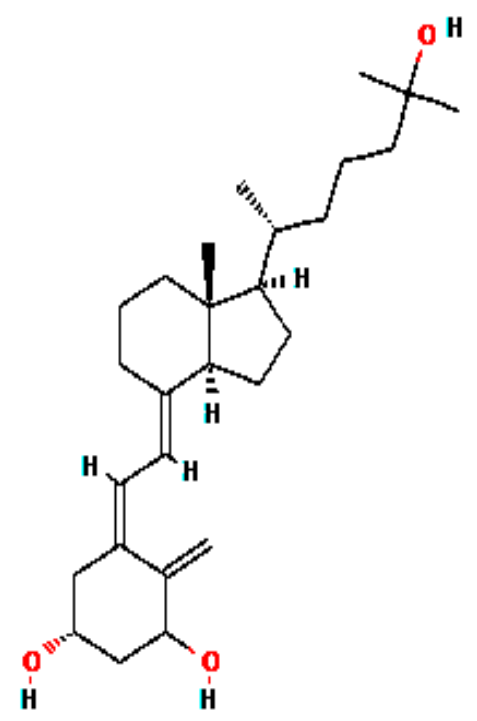

Figure 1: 1,25-dihydroxyvitamin D3

Retrieved from: National Center for Biotechnology PubChem Compound Database [36] Vitamin C (l-ascorbic acid)

Ascorbic acid, a water-soluble form of vitamin C, functions as a potent antioxidant and detoxifier [40], Pro-inflammatory cytokines contribute to the severe inflammation of the lungs as observed in severe cases of SARSCoV-2 [1,3]. Scavengers of reactive oxygen species, such as vitamin C, may play an influential role in minimizing cytokine storm and alleviating tissue damage [3,25]. Antioxidants found in vitamin $\mathrm{C}$ enhance $\mathrm{T}$ lymphocyte response, natural killer cell activity, and interleukin-2 production [28,29]. Vitamin C supports the maintenance of gap, tight and adherens junctions in epithelial barriers, increases serum antibody levels, and increases lymphocyte production and differentiation [22,23]. Vitamin $\mathrm{C}$ has also been shown to have anti-histamine properties [44,52].

Vitamin C deficiency has been linked to the development of viral and bacterial pneumonia [24,32,53]. Two randomized controlled trials identified a dose-dependent relationship between levels of vitamin $\mathrm{C}$ and the duration of symptomatic respiratory infections with vitamin $\mathrm{C}$ doses of 6-8g/day [24].<smiles>O=C1O[C@H]([C@@H](O)CO)C(O)=C1O</smiles>

Figure 2: 1-ascorbic acid

Retrieved from: National Center for Biotechnology PubChem Compound Database [40] Vitamin E ( $\alpha$-tocopherol)

Vitamin $\mathrm{E}$ is a fat-soluble vitamin and anti-oxidant bioavailable in the form of $\alpha$-tocopherol [39]. $\alpha$-tocopherol is a scavenger of reactive oxygen species, neutralizing free radicals, and influential in minimizing cytokine storm and tissue damage [3,25]. $\alpha$-tocopherol prevents protein oxidation, 
lipid perioxidation, and inhibits protein kinase C (PKC) mediated pathways [39]. Antioxidants found in $\alpha$-tocopherol enhance $T$ lymphocyte response, natural killer cell activity and interleukin-2 production $[28,29]$.

$\alpha$-tocopherol inhibits platelet aggregation, promotes vasodilation, stabilizes membranes, and inhibits angiogenesis [39].
Deficiency of $\alpha$-tocopherol reduces adaptive immune response, hindering $\mathrm{B}$ and $\mathrm{T}$ lymphocyte function [4]. The utilization of exogenous vitamin $\mathrm{E}$ supplementation is controversial and may increase all-cause mortality [37]. It should be noted that simultaneous vitamin $\mathrm{C}$ and vitamin $\mathrm{E}$ supplementation has been shown to increase pneumonia and tuberculosis risk when compared to vitamin $\mathrm{C}$ supplementation alone [26,27].

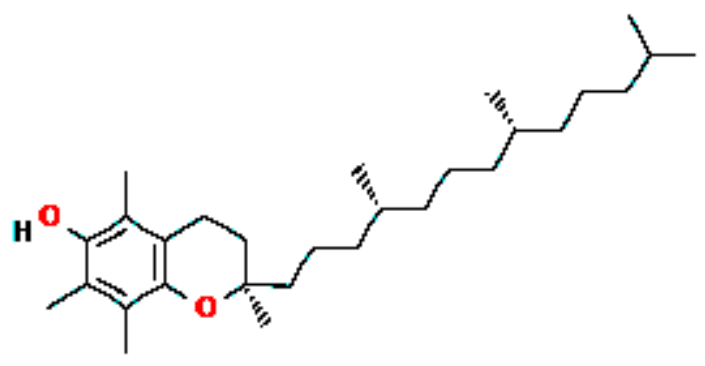

\section{Figure 3: $\alpha$-tocopherol \\ Retrieved from: National Center for Biotechnology PubChem Compound Database [39]}

Vitamin A ( $\beta$-carotene)

$\beta$-carotene is a naturally occurring retinol, pro-vitamin A $[41,46]$. $\beta$ carotene has antineoplastic properties and is a scavenger of reactive oxygen species $[3,25,41]$. Antioxidants found in $\beta$-carotene also enhance $\mathrm{T}$ lymphocyte response, natural killer cell activity and interleukin-2 production [28,29]. Vitamin A has been shown to reduce the overall severity and consequent fatalities associated with HIV, malaria, and measles [48]. An animal model study linked increased rates of infectious bronchitis coronavirus in chickens with vitamin A deficiency $[44,49]$

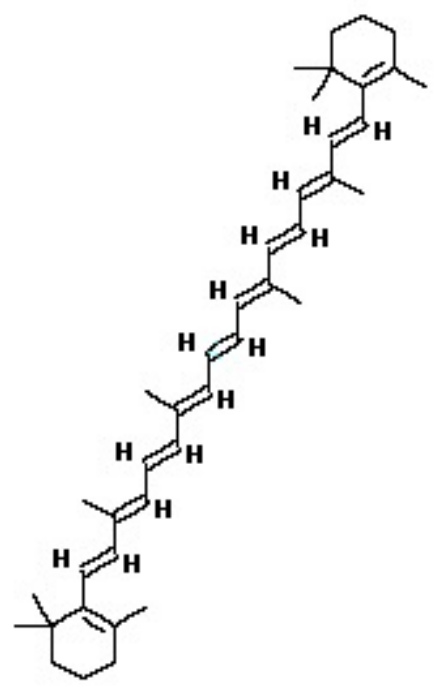

Retrieved from: National Center for Biotechnology PubChem Compound Database [41] Vitamin B2 (riboflavin)

Vitamin B2 (riboflavin) is a water-soluble precursor to flavin mononucleotide (FMN) and flavin adenine dinucleotide (FAD) [57]. FMN and FAD are essential in respiration, metabolism of fats, proteins, carbohydrates, and in detoxification mediated by glutathione reductase [57]. Riboflavin and UV light has been shown to reduce human plasma viral titer levels of MERS- CoV [44,50]. 


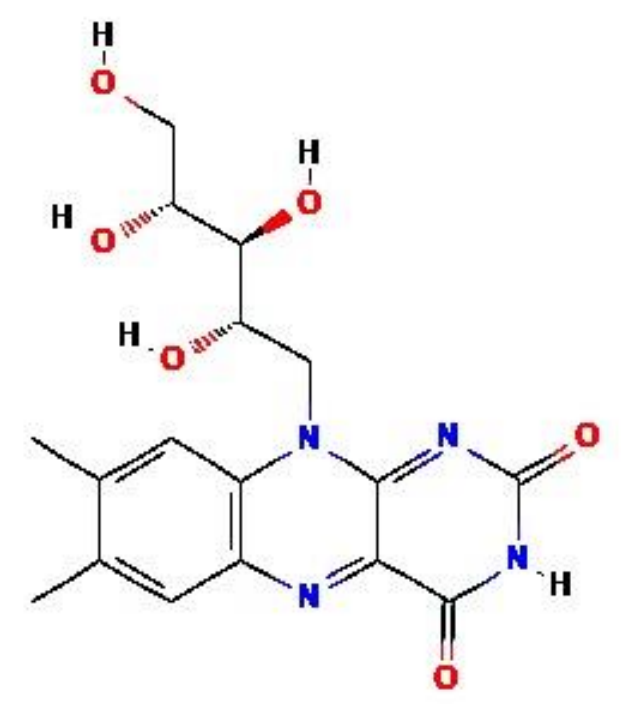

\section{Retrieved from: National Center for Biotechnology PubChem Compound Database [57]} Vitamin B3 (nicotinic acid)

Vitamin B3 (Nicotinic acid), also called nicotinamide or niacin, is a water-soluble vitamin that promotes DNA repair, energy metabolism, vasodilation, and reduced serum lipids [58]. Nicotinic acid lowers low density lipoprotein cholesterol and raises high density lipoprotein cholesterol [58]. Nicotinic acid has anti-inflammatory properties and has been shown to inhibit pulmonary neutrophil infiltration in cases of ventilator- induced pulmonary injury, albeit, increasing overall hypoxia [44,51]. Serum aminotransferase levels must be monitored with the administration of chronic or high dose nicotinic acid [58].<smiles>O=C(O)c1cccnc1</smiles>

\section{Figure 6: Nicotinic Acid}

Retrieved from: National Center for Biotechnology PubChem Compound Database [58]

Vitamin B6 (pyridoxine)

Pyridoxine is the 4-methanol form of vitamin B6, a water soluble vitamin that acts as a coenzyme in amino acid and neurotransmitter synthesis [63].
Large dose (50-100 mg/day) pyridoxine administration has been shown to increase $\mathrm{T}$ lymphocyte production and activity $[61,62]$. 
<smiles>Cc1ncc(CO)c(CO)c1O</smiles>

\section{Retrieved from: National Center for Biotechnology PubChem Compound Database [63]} Vitamin B12 (cyanocobalamin)

Vitamin B12 (cyanocobalamin) is an immunomodulator for cellular immunity [62]. Cyanocobalamin functions to support the hematopoietic, nervous and immune systems [59,60]. Exogenous cyanocobalamin is necessary in the myelin synthesis, cellular growth, cellular reproduction, and erythropoiesis [59, 61]. Cyanocobalamin deficiency may lead to megaloblastic anemia, disruption of neuron myelin sheath integrity, and reduced protective immune response [12]. Methyl-B12 administration has been shown to increase leukocyte, lymphocyte, $\mathrm{CD} 8+$ cell, and natural killer cell production $(\mathrm{P}<0.05)$ [62]. Vitamin B12 deficiencies lead to CD8+ and natural killer cell suppression [62]. Restoration and augmentation of cyanocobalamin levels can be achieved in patients with COVID-19 with methyl-B12 administration [62].

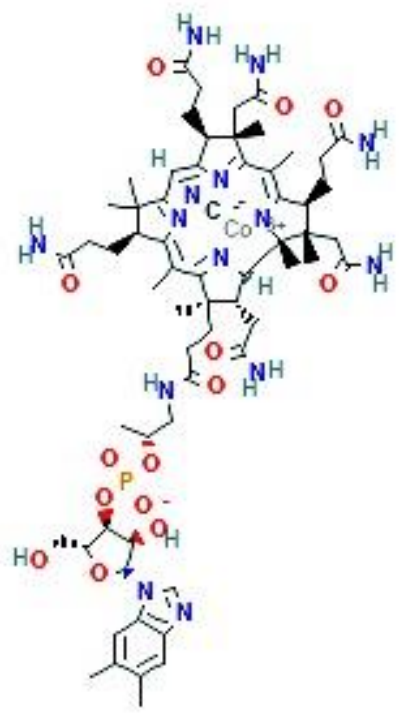

Figure 8: Cyanocobalamin

Retrieved from: National Center for Biotechnology PubChem Compound Database [59]

\section{Zinc}

Zinc supports both innate and acquired immune responses [44]. Zinc supplementation has been shown in several randomized controlled trials and in a meta-analysis to reduce the incidence and the duration of acute respiratory infections by $35 \%$ and 2 days, respectively. This effect has not been found to be dose dependent [30,31]. Zinc has been shown in vitro to inhibit SARS-CoV RNA polymerase activity and viral replication [2]. Zinc lozenges are shown to reduce viral respiratory infection duration and severity if utilized within 24 hours of the onset of respiratory symptoms [30]. Zinc lozenges may reduce the binding efficacy of the SARS-CoV-2 virus to the host oral mucosa $[30,34,35]$.

\section{Iron}

Iron deficiency is a contributor to the development of lower respiratory tract infections [52]. Excess iron, however, can lead to oxidative damage 
and viral mutation [44,52]. Iron deficiency should be avoided in the prevention of SARS-CoV-2 acquisition. In patients with diagnosed SARS-CoV-2, elevated serum ferritin levels are observed in patients with SARS-CoV-2 induced cytokine storm [42]. One hemoglobin molecule is comprised $2-\alpha$ and $2-\beta$ subunits. Each subunit has one iron-bound heme complex [42]. Elevated serum ferritin suggests that excessive iron levels accumulating due to SARS-CoV-2 interfering with the iron-bound heme complex [42]. Thus, supplementation of iron should be avoided in patients with diagnosed SARS-CoV-2 infection.

\section{Selenium}

Selenium deficiency may induce viral genome mutation of RNA viruses. These mutations may amplify virulence in the host, creating increasing the magnitude and severity of the resultant infection [44]. Selenium, synergistically with vitamin $\mathrm{E}$, acts as a scavenger of reactive oxygen species, also influential in minimizing cytokine storm and tissue damage $[3,25,42]$.

\section{Omega- 3 Long- chain Polyunsaturated Fatty Acids}

Omega- 3 polyunsaturated fatty acids promote anti- inflammatory effects and are precursors to protectins and resolvins [44]. Omega- 6 polyunsaturated fatty acids promote pro- inflammatory effects and are precursors to prostaglandins and leukotrienes [44]. A delicate balance of omega- 3 and omega- 6 polyunsaturated fatty acids must be maintained to minimize pro- inflammatory effects. Protectin D1 is an omega- 3 polyunsaturated fatty acid derived lipid mediator shown to reduce influenza viral replication, reduce influenza mortality in animal models, and have been shown to target hepatitis $\mathrm{C}$ viral replication $[44,55,56]$.

\begin{tabular}{|c|c|c|}
\hline Micronutrient & Sources & Selected Physiologic Effects \\
\hline $\begin{array}{l}\text { Vitamin D } \\
(1,25 \text { dihydroxyvitamin } \\
\left.\mathrm{D}_{3}\right)\end{array}$ & $\begin{array}{l}\text { Green vegetables, legumes, egg yolks, } \\
\text { cheese, beef, tuna, mackerel, soy [67] }\end{array}$ & $\begin{array}{l}\downarrow \text { Pro-inflammatory cytokines TNF- } \alpha \\
\text { and INF- } \gamma \\
\uparrow \text { Anti-inflammatory cytokines } \\
\text { Epithelial barrier support } \\
\uparrow \mathrm{O}_{2} \text { carrying capacity }\end{array}$ \\
\hline $\begin{array}{l}\text { Vitamin C } \\
\text { (1-ascorbic acid) }\end{array}$ & Green vegetables, citrus fruits [40] & 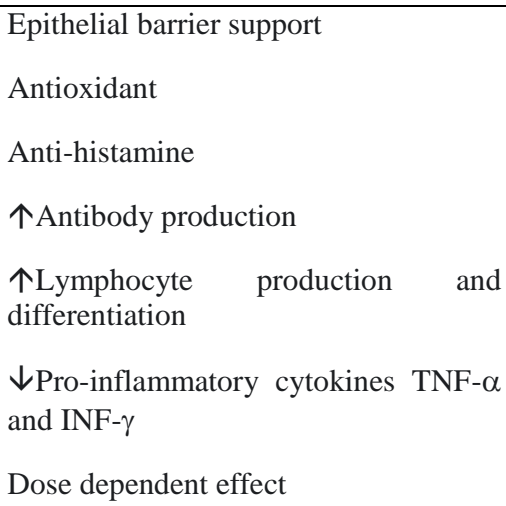 \\
\hline $\begin{array}{l}\text { Vitamin B2 } \\
\text { (riboflavin) }\end{array}$ & $\begin{array}{l}\text { Eggs, leafy greens, liver, kidney, heart, } \\
\text { milk, malted barley, yeast [57] }\end{array}$ & $\begin{array}{l}\text { FMN and FAD production } \\
\text { Respiration } \\
\text { Metabolism of macronutrients } \\
\text { Detoxification }\end{array}$ \\
\hline $\begin{array}{l}\text { Vitamin B3 (Nicotinic } \\
\text { acid) }\end{array}$ & $\begin{array}{l}\text { Tuna, salmon, legumes, coffee, } \\
\text { vegetables, poultry [67] }\end{array}$ & $\begin{array}{l}\text { DNA repair } \\
\text { Energy metabolism } \\
\text { Vasodilation } \\
\downarrow \text { LDL } \\
\uparrow \mathrm{HDL}\end{array}$ \\
\hline $\begin{array}{l}\text { Vitamin B6 } \\
\text { (pyroxidine) }\end{array}$ & Eggs, vegetables, meats, liver [67] & 个lymphocyte production \\
\hline
\end{tabular}




\begin{tabular}{|c|c|c|}
\hline $\begin{array}{l}\text { Vitamin B12 } \\
\text { (cyanocobalamin) }\end{array}$ & $\begin{array}{l}\text { Salmon, egg, clams, liver, canned tuna, } \\
\text { trout, beef [67] }\end{array}$ & $\begin{array}{l}\text { 个 leukocyte production } \\
\uparrow \text { lymphocyte production } \\
\uparrow \mathrm{CD} 8+\text { cell production } \\
\uparrow \text { Natural killer cell production }\end{array}$ \\
\hline $\begin{array}{l}\text { Vitamin E } \\
\text { ( } \alpha \text {-tocopherol) }\end{array}$ & $\begin{array}{l}\text { Plant-based oils, nuts, seeds, grains, nuts, } \\
\text { fruits, vegetables[38] }\end{array}$ & $\begin{array}{l}\text { Epithelial barrier support } \\
\text { Antioxidant } \\
\downarrow \text { Pro-inflammatory cytokines TNF- } \alpha \\
\text { and INF- } \gamma \\
\text { 个Lymphocyte activity } \\
\text { 个Natural killer cell activity } \\
\text { 个IL-2 production } \\
\downarrow \text { Platelet aggregation } \\
\text { Vasodilation } \\
\uparrow M e m b r a n e ~ s t a b i l i z a t i o n \\
\downarrow \text { Angiogenesis }\end{array}$ \\
\hline $\begin{array}{l}\text { Vitamin A } \\
(\beta \text {-carotene })\end{array}$ & $\begin{array}{l}\text { Orange, yellow and green leafy vegetables } \\
\text { and fruits[41] }\end{array}$ & $\begin{array}{l}\text { Antioxidant } \\
\text { Antineoplastic } \\
\text { 个Lymphocyte activity } \\
\text { 个Natural killer cell activity } \\
\text { 个IL-2 production }\end{array}$ \\
\hline Iron & $\begin{array}{l}\text { Beans, lentils, tofu, potatoes, whole grain } \\
\text { bread, dark leafy greens [67] }\end{array}$ & $\begin{array}{l}\text { Essential in } \mathrm{O}_{2} \text { carrying capacity } \\
\text { 个Serum iron levels observed in SARS- } \\
\mathrm{CoV}-2 \text { induced cytokine storm }\end{array}$ \\
\hline Zinc & $\begin{array}{l}\text { Oysters, whole grains, milk, beans, } \\
\text { chickpeas, nuts, poultry[67] }\end{array}$ & $\begin{array}{l}\downarrow \text { SARS-CoV RNA polymerase } \\
\text { activity } \\
\downarrow \text { Viral replication of SARS-CoV }\end{array}$ \\
\hline Selenium & $\begin{array}{l}\text { Brazil nuts, sunflower seeds, egg, spinach, } \\
\text { tofu, brown rice[67] }\end{array}$ & Antioxidant \\
\hline Omega-3 Fatty Acids & $\begin{array}{l}\text { Fish oil, walnuts, pumpkin seeds, sesame } \\
\text { seeds, vegetable oils, durum wheat }[44,67]\end{array}$ & Anti- inflammatory effects \\
\hline
\end{tabular}

Table 1: Micronutrient Optimization in Maintaining Host Immunocompetenc

\section{Discussion}

\section{Anti-aging gene Sirtuin 1 (SIRT1)}

Maintaining adequate micronutrient intake to optimize host immune response is indicated in both the prevention and treatment of SARS-CoV2. Malnutrition is linked to insufficient plasma protein level of anti-aging gene Sirtuin 1 (SIRT1) [70,71]. SARS-CoV-2 deactivates and represses SIRT1 [69]. SIRT1, dependent on nicotinamide dinucleotide (NAD+) for deacetylation, contributes to the prevention and reversal of chronic diseases that impair the host immune response, such as NAFLD, diabetes, neurodegenerative diseases and obesity [69,70]. SIRT1 functions in global DNA reparation, fat differentiation, insulin sensitivity, neurogenesis, inflammation, genetic stability and reduces proinflammatory cytokines [69,70]. SIRT1 deactivation and repression observed in the SARS-CoV-2 infection may contribute to varying levels of disease severity [69]. Micronutrient optimization in the SARS-CoV-2 infected host is necessary in the optimization for plasma protein SIRT1 levels and in the mitigation of anti-aging gene SIRT1 inactivation [71]. 
Exogenous vitamin D increases plasma protein levels of SIRT1 [73]. Exogenous vitamin $\mathrm{E}$ has also been shown to influence plasma protein levels of SIRT1 [73]. NAD+, essential for SIRT1 deacetylation, is synthesized from its precursor, vitamin B3 (nicotinic acid) [73].

\section{Angiotensin-converting enzyme-2 (ACE2)}

Angiotensin-converting enzyme-2 (ACE2), a physiologic enzyme of the renin-angiotensin-aldosterone system (RAAS), is the receptor for the SARS-CoV-2 virus [74]. Levels of the enzyme ACE2 has been speculated as a contributor to varying degrees of the 2019 coronavirus infection severity [74]. Binding of SARS-CoV-2 virus to the ACE2 receptor results in ACE2 down-regulation, precipitating neutrophil sequestration, an exaggerated pro-inflammatory response, and a hypoxia induced release of renin $[76,77]$.

Vitamin D (1,25-dihydroxyvitamin $\mathrm{D}_{3}$ ) is a known modulator of RAAS, thus exogenous vitamin D may reduce RAAS activity through the reduction of renin expression [75,77]. 1,25-dihydroxyvitamin $\mathrm{D}_{3}$ can be acquired exogenously or endogenously through the synthesis of steroid hormone, cholecalciferol, when the host is exposed to ultraviolet light [36.44.47].

\section{Micronutrient Optimization}

Vitamin D (1,25-dihydroxyvitamin $\left.\mathrm{D}_{3}\right)$ has been shown to reduce the risk of host viral respiratory infection acquisition [1,5-13]. 1,25dihydroxyvitamin $\mathrm{D}_{3}$ reduces pro-inflammatory cytokines, increases antiinflammatory cytokines, enhances epithelial barrier support, reduces the rate of viral replication, reduces RAAS activity through the reduction of renin expression, and increases host oxygen carrying capacity [1,13-21]. Exogenous vitamin D should be evaluated as an adjuvant therapy in the prevention and treatment of SARS-CoV-2.

Vitamin C (1-ascorbic acid) is a potent antioxidant that may play an important role in mitigating cytokine storm and alleviating tissue damage $[3,25,40]$. L-ascorbic acid enhances epithelial barrier support, increases lymphocyte production and differentiation, and reduces pro-inflammatory cytokines [22,23,28,29]. Vitamin E ( $\alpha$-tocopherol) is a potent antioxidant that may also play a significant role in alleviating cellular damage, enhancing T lymphocyte response, promoting natural killer cell activity, increasing interleukin-2 production, and mitigating host cytokine storm $[3,25,28,29]$. The utilization of exogenous vitamin E supplementation is controversial and may increase all-cause mortality [37]. Concurrent exogenous vitamin $\mathrm{C}$ and vitamin $\mathrm{E}$ supplementation should also be avoided [26,27].

Vitamin A ( $\beta$-carotene) is a potent antioxidant and scavenger of reactive oxygen species shown to enhance $\mathrm{T}$ lymphocyte response, natural killer cell activity and interleukin-2 production $[3,25,28,29,41]$. Increased rates of infectious bronchitis coronavirus in chickens has been linked to vitamin A deficiency [44,49]. Exogenous vitamins D, A, and C should be evaluated as adjuvant therapies in the prevention and treatment of SARS-CoV-2.

B vitamins also play a critical role in maintaining host immunocompetence. Vitamin B2 (riboflavin) has been shown to shown to reduce human plasma viral titer levels of MERS- CoV [44,50].
Vitamin B3 (Nicotinic acid) is essential for SIRT1 deacetylation [73]. Nicotinic acid has anti-inflammatory properties and has been shown to inhibit pulmonary neutrophil infiltration in cases of ventilator- induced pulmonary injury, albeit, increasing overall hypoxia [44,51]. Large dose (50-100 mg/day) vitamin B6 (pyridoxine) administration has been shown to increase $\mathrm{T}$ lymphocyte production and activity [61,62]. Methyl-B12 administration has been shown to increase leukocyte, lymphocyte, CD8+ cell, and natural killer cell production $(\mathrm{P}<0.05)$ [62]. Vitamin B12 deficiencies lead to CD8+ and natural killer cell suppression [62]. Restoration and augmentation of cyanocobalamin levels can be achieved in patients with COVID-19 with methyl-B12 administration [62].

Zinc has been shown in vitro to inhibit SARS-CoV RNA polymerase activity and viral replication [2]. Zinc lozenges may reduce the binding efficacy of the SARS-CoV-2 virus to host oral mucosa [30,34,35]. The utilization of exogenous zinc should be evaluated for use in SARS-CoV2 infections and initiated within 24 hours of the onset of respiratory symptoms [30].

Elevated serum ferritin in severe SARS-CoV-2 infections, suggest that excessive plasma iron levels accumulate in this state due to SARS-CoV2 interfering with the iron-bound heme complex ${ }^{42}$. Exogenous iron should be avoided in these patients. Selenium, synergistically with vitamin E, acts as a scavenger of reactive oxygen species, also influential in minimizing cytokine storm and tissue damage $[3,25,44]$. A delicate balance of omega- 3 and omega- 6 polyunsaturated fatty acids must be maintained to minimize pro- inflammatory effects. Protectin D1, an omega- 3 polyunsaturated fatty acid, should be evaluated as an adjuvant therapy in the reduction of cytokine induced pro-inflammatory effects and as a potential inhibitor of SARS-CoV-2 viral replication [44,55,56].

\section{Conclusion}

The immune supportive mechanisms and physiologic effects of various micronutrients are multifaceted. Micronutrient optimization is critical in maintaining host immunocompetence. Maintaining adequate micronutrient intake to optimize host immune response is indicated in both the prevention and treatment of SARS-CoV-2. Further investigations should be performed to evaluate the utilization of exogenous micronutrient therapies as an adjunct to the treatment of SARS-CoV-2. Vigilance should be paid to maintaining adequate micronutrient intake to optimize host immune response in both the prevention and treatment of SARS-CoV-2.

\section{Ethical Declarations}

The author declares that no conflicts of interest exist.

\section{References}

1) Grant WB, Lahore H, McDonnell SL, et al. (2020) Evidence that Vitamin D Supplementation Could Reduce Risk of Influenza and COVID-19 Infections and Deaths. Nutrients. 12(4):E988. Published 2020 Apr 2.

2) Velthuis, Aartjan J. W. Te, et al. (2010) "Zn2+ Inhibits Coronavirus and Arterivirus RNA Polymerase Activity In Vitro 
and Zinc Ionophores Block the Replication of These Viruses in Cell Culture.” PLoS Pathogens, vol. 6, no. 11,

3) Jang, In-Surk et al. (2014) "Effects of Vitamin C or E on the Pro-inflammatory Cytokines, Heat Shock Protein 70 and Antioxidant Status in Broiler Chicks under Summer Conditions." Asian-Australasian journal of animal sciences vol. 27,5 749-756.

4) Maggini S, Pierre A, Calder PC. (2018) Immune Function and Micronutrient Requirements Change over the Life Course. Nutrients. 10(10):1531. Published 2018 Oct 17.

5) Beard, J.A.; Bearden, A.; Striker, R. Vitamin D and the antiviral state. J. Clin. Virol. 2011, 50, 194-200. Hewison, M. An update on vitamin D and human immunity. Clin. Endocrinol. 2012, 76, 315-325.

6) Greiller, C.L.; Martineau, A.R. Modulation of the immune response to respiratory viruses by vitamin D. Nutrients. 2015, 7, $4240-4270$.

7) Wei, R.; Christakos, S. Mechanisms Underlying the Regulation of Innate and Adaptive Immunity by Vitamin D. Nutrients. 2015, 7, 8251-8260.

8) Coussens, A.K. The role of UV radiation and vitamin D in the seasonality and outcomes of infectious disease. Photochem. Photobiol. Sci. 2017, 16, 314-338.

9) Lang, P.O.; Aspinall, R. Vitamin D Status and the Host Resistance to Infections: What It Is Currently (Not) Understood. Clin. Ther. 2017, 39, 930-945.

10) Gruber-Bzura, B.M. Vitamin D and Influenza-Prevention or Therapy? Int. J. Mol. Sci. 2018, 19, 2419.

11) Rondanelli, M.; Miccono, A.; Lamburghini, S.; Avanzato, I.; Riva, A.; Allegrini, P.; Faliva, M.A.; Peroni, G.; Nichetti, M.; Perna, S. Self-Care for Common Colds: The Pivotal Role of Vitamin D, Vitamin C, Zinc, and Echinacea in Three Main Immune Interactive Clusters (Physical Barriers, Innate and Adaptive Immunity) Involved during an Episode of Common Colds-Practical Advice on Dosages and on the Time to Take These Nutrients/Botanicals in order to Prevent or Treat Common Colds. Evid. Based Complement. Alternat. Med. 2018, 2018, 5813095.

12) Gombart, A.F.; Pierre, A.; Maggini, S. A Review of Micronutrients and the Immune System-Working in Harmony to Reduce the Risk of Infection. Nutrients 2020, 12, 236.

13) Schwalfenberg, G.K. A review of the critical role of vitamin D in the functioning of the immune system and the clinical implications of vitamin D deficiency. Mol. Nutr. Food Res. 2011, 55, 96-108.

14) Huang, C.; Wang, Y.; Li, X.; Ren, L.; Zhao, J.; Hu, Y.; Zhang, L.; Fan, G.; Xu, J.; Gu, X.; et al. Clinical features of patients infected with 2019 novel coronavirus in Wuhan, China. Lancet 2020 .

15) Sharifi, A.; Vahedi, H.; Nedjat, S.; Rafiei, H.; HosseinzadehAttar, M.J. Effect of single-dose injection of vitamin D on immune cytokines in ulcerative colitis patients: A randomized placebo-controlled trial. APMIS 2019, 127, 681-687.

16) Youssef, D.A.; Ranasinghe, T.; Grant, W.B.; Peiris, A.N. Vitamin D's potential to reduce the risk ofhospital-acquired infections. Derm. Endocrinol. 2012, 4, 167-175.

17) Quraishi, S.A.; Bittner, E.A.; Blum, L.; Hutter, M.M.; Camargo, C.A., Jr. Association between preoperative 25hydroxyvitamin D level and hospital-acquired infections following Roux-en-Y gastric bypass surgery. JAMA Surg. 2014, 149, 112-118.

18) Laviano, E.; Sanchez Rubio, M.; Gonzalez-Nicolas, M.T.; Palacian, M.P.; Lopez, J.; Gilaberte, Y.; Calmarza, P.; Rezusta, A.; Serrablo, A. Association between preoperative levels of 25hydroxyvitamin D and hospital-acquired infections after hepatobiliary surgery: A prospective study in a third-level hospital. PLOS ONE 2020, 15, e0230336.

19) Han, J.E.; Jones, J.L.; Tangpricha, V.; Brown, M.A.; Brown, L.A.S.; Hao, L.; Hebbar, G.; Lee, M.J.; Liu, S.; Ziegler, T.R.; et al. High Dose Vitamin D Administration in Ventilated Intensive Care Unit Patients: A Pilot Double Blind Randomized Controlled Trial. J. Clin. Transl. Endocrinol. 2016, 4, 59-65.

20) Smith, E.M.; Jones, J.L.; Han, J.E.; Alvarez, J.A.; Sloan, J.H.; Konrad, R.J.; Zughaier, S.M.; Martin, G.S.; Ziegler, T.R.; Tangpricha, V. High-Dose Vitamin D3 Administration Is Associated With Increases in Hemoglobin Concentrations in Mechanically Ventilated Critically Ill Adults: A Pilot DoubleBlind, Randomized, Placebo-Controlled Trial. JPEN J. Parenter. Enter. Nutr. 2018, 42, 87-94.

21) Kościuczuk EM, Lisowski P, Jarczak J, et al. Cathelicidins: family of antimicrobial peptides. A review. Mol Biol Rep. 2012;39(12):10957-10970.

22) Haryanto B., Suksmasari T., Wintergerst E., Maggini S. Multivitamin supplementation supports immune function and ameliorates conditions triggered by reduced air quality. Vitam. Miner. 2015; 4:1-15.

23) Carr A., Maggini S. Vitamin $C$ and immune function. Nutrients. 2017; 9:1211.

24) Vitamin C and Infections. Hemilä H. Nutrients. 2017 Mar 29; 9(4)

25) Packer, J.E.; Slater, T.F.; Wilson, R.L. Direct observation of a free radical interaction between vitamin $\mathrm{E}$ and vitamin $\mathrm{C}$. Nature 1979, 278, 737-738. 
26) Hemilä, H.; Kaprio, J. Modification of the effect of vitamin E supplementation on the mortality of male smokers by age and dietary vitamin C. Am. J. Epidemiol. 2009, 169, 946-953.

27) Hemilä, H.; Kaprio, J. Vitamin E supplementation and pneumonia risk in males who initiated smoking at an early age: Effect modification by body weight and vitamin C. Nutr. J. 2008, 7, 33.

28) Chandra RK. Effect of vitamin and trace-element supplementation on immune responses and infection in elderly subjects. Lancet. 1992; 340:1124-1127.

29) Muscogiuri, G., Barrea, L., Savastano, S. et al. Nutritional recommendations for CoVID-19 quarantine. Eur J Clin Nutr (2020).

30) Hemilä H, Fitzgerald JT, Petrus EJ, Prasad A. Zinc Acetate Lozenges May Improve the Recovery Rate of Common Cold Patients: An Individual Patient Data Meta-Analysis. Open Forum Infect Dis. 2017;4(2):ofx059. Published 2017 Apr 3.

31) Roth DE, Richard SA, Black RE. Zinc supplementation for the prevention of acute lower respiratory infection in children in developing countries: meta-analysis and meta-regression of randomized trials. International journal of epidemiology. 2010 Jun 1;39(3):795-808.

32) Hemilä $H$, Louhiala $P$. Vitamin $C$ for preventing and treating pneumonia. Cochrane database of systematic reviews. 2013(8).

33) Shankar AH, Prasad AS. Zinc and immune function: the biological basis of altered resistance to infection. Am J Clin Nutr. 1998 Aug;68(2 Suppl):447S-463S.

34) Singh M, Das RR. Zinc for the common cold. Cochrane Database of Systematic Reviews 2013, Issue 6. Art. No.: CD001364.

35) National Center for Biotechnology Information. PubChem Database. Cholecalciferol, CID $=5280795$,

36) Miller ER, 3rd, Pastor-Barriuso R, Dalal D, Riemersma RA, Appel LJ, Guallar E. Meta-analysis: high-dosage vitamin E supplementation may increase all-cause mortality. Ann Intern Med. 2005;142:37-46.

37) Institute of Medicine. Dietary reference intakes for vitamin $C$, vitamin E, selenium, and carotenoids. Washington, D.C.: National Academies Press; 2000.

38) National Center for Biotechnology Information. PubChem Database. Vitamin E, CID $=14985$,

39) National Center for Biotechnology Information. PubChem Database. Ascorbic acid, CID=54670067,

40) National Center for Biotechnology Information. PubChem Database. beta-Carotene, CID $=5280489$,
41) COVID-19: consider cytokine storm syndromes and immunosuppression

42) Mehta, Puja et al. The Lancet, Volume 395, Issue 10229, 1033 $-1034$

43) Wenzhong, Liu; Hualan, Li (2020): COVID-19: Attacks the 1Beta Chain of Hemoglobin and Captures the Porphyrin to Inhibit Human Heme Metabolism. ChemRxiv.

44) Zhang L, Liu Y. Potential interventions for novel coronavirus in China: A systematic review. J Med Virol. 2020;92(5):479490.

45) Laviano A, Koverech A, Zanetti M. Nutrition support in the time of SARS-CoV-2 (COVID-19) [published online ahead of print, 2020 Apr 2]. Nutrition. 2020;110834.

46) Grune T, Lietz G, Palou A, et al. Beta-carotene is an important vitamin A source for humans. J Nutr. 2010;140(12):2268S2285 S.

47) Wacker M, Holick MF. Sunlight and Vitamin D: A global perspective for health. Dermatoendocrinol. 2013;5(1):51-108.

48) Semba RD. Vitamin A and immunity to viral, bacterial and protozoan infections. Proc Nutr Soc. 1999;58:719- 727.

49) West CE, Sijtsma SR, Kouwenhoven B, Rombout JH, van der Zijpp AJ. Epithelia- damaging virus infections affect vitamin A status in chickens. $J$ Nutr. 1992;122:333- 339.

50) Keil SD, Bowen R, Marschner S. Inactivation of Middle East respiratory syndrome coronavirus (MERS- CoV) in plasma products using a riboflavin- based and ultraviolet light- based photochemical treatment. Transfusion. 2016;56:2948- 2952.

51) Jones HD, Yoo J, Crother TR, et al. Nicotinamide exacerbates hypoxemia in ventilator- induced lung injury independent of neutrophil infiltration. PLOS One. 2015;10:e0123460.

52) Field CJ, Johnson IR, Schley PD. Nutrients and their role in host resistance to infection. J Leukoc Biol. 2002;71:16- 32.

53) Hemila H. Vitamin $C$ intake and susceptibility to pneumonia. Pediatr Infect Dis J. 1997;16:836- 837.

54) Jayaweera J, Reyes M, Joseph A. Childhood iron deficiency anemia leads to recurrent respiratory tract infections and gastroenteritis. Sci Rep. 2019;9:12637.

55) Morita M, Kuba K, Ichikawa A, et al. The lipid mediator protectin D1 inhibits influenza virus replication and improves severe influenza. Cell. 2013;153:112- 125.

56) Leu GZ, Lin TY, Hsu JT. Anti- HCV activities of selective polyunsaturated fatty acids. Biochem Biophys Res Commun. 2004;318:275- 280.

57) National Center for Biotechnology Information. PubChem Database. Riboflavin, CID $=493570$, 
58) National Center for Biotechnology Information. PubChem Database. Nicotinic acid, CID=938,

59) National Center for Biotechnology Information. PubChem Database. Cyanocobalamin, CID $=5311498$,

60) Hardman, J.G., L.E. Limbird, P.B. Molinoff, R.W. Ruddon, A.G. Goodman (eds.). Goodman and Gilman's The Pharmacological Basis of Therapeutics. 9th ed. New York, NY: McGraw-Hill, 1996., p. 1330

61) McEvoy, G.K. (ed.). American Hospital Formulary Service Drug Information 2000. Bethesda, MD: American Society of Health-System Pharmacists, Inc. 2000 (Plus Supplements), p. 3325

62) Tamura J, Kubota K, Murakami H, et al. Immunomodulation by vitamin B12: augmentation of CD8+ $\mathrm{T}$ lymphocytes and natural killer (NK) cell activity in vitamin B12-deficient patients by methyl-B12 treatment. Clin Exp Immunol. 1999;116(1):28-32.

63) Tamura J, Kubota K, Murakami H, et al. Immunomodulation by vitamin $\mathrm{B} 12$ : augmentation of $\mathrm{CD} 8+\mathrm{T}$ lymphocytes and natural killer (NK) cell activity in vitamin B12-deficient patients by methyl-B12 treatment. Clin Exp Immunol. 1999;116(1):28-32.

64) Huang YC, Lan PH, Cheng CH, Lee BJ, Kan MN. Vitamin B6 intakes and status of mechanically ventilated critically ill patients in Taiwan. Eur J Clin Nutr. 2002;56(5):387-392.

65) Cheng CH, Chang SJ, Lee BJ, Lin KL, Huang YC. Vitamin B6 supplementation increases immune responses in critically ill patients. Eur J Clin Nutr. 2006;60(10):1207-1213.

66) National Center for Biotechnology Information. PubChem Database. Pyridoxine, CID $=1054$,

67) U.S. Department of Agriculture, Agricultural Research Service. FoodData Central, 2019.

68) Cao, X. COVID-19: immunopathology and its implications for therapy. Nat Rev Immunol (2020).

This work is licensed under Creative Commons Attribution 4.0 License

To Submit Your Article Click Here: Submit Article DOI:10.31579/2690-4861/024

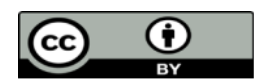
BY Commons Attribution 4.0 License
69) Martins, IJ. COVID-19 Infection and Anti-Aging Gene Inactivation". Acta Scientific Nutritional Health 4.5 (2020): 0102.

70) Lee $S$, Lee J, Lee $H$, Min $K$. Sirtuin signaling in cellular senescence and aging. BMB Rep. 2019; 52:24-34.

71) Assar ME, Angulo J, Walter S, et al. Better Nutritional Status Is Positively Associated with mRNA Expression of SIRT1 in Community-Dwelling Older Adults in the Toledo Study for Healthy Aging. The Journal of Nutrition. 2018;148(9):14081414.

72) Safarpour P, Daneshi-Maskooni M, Vafa M, et al. Vitamin D supplementation improves SIRT1, Irisin, and glucose indices in overweight or obese type 2 diabetic patients: a double-blind randomized placebo-controlled clinical trial. BMC Fam Pract. 2020;21(1):26. Published 2020 Feb 7.

73) Zillikens MC, Meurs JBV, Rivadeneira F, et al. Interactions between dietary vitamin E intake and SIRT1 genetic variation influence body mass index. The American Journal of Clinical Nutrition. 2010;91(5):1387-1393.

74) Vaduganathan M, Vardeny O, Michel T, McMurray JJV, Pfeffer MA, Solomon SD. Renin-angiotensin-aldosterone system Iinhibitors in patients with Covid-19. $N$ Engl J Med. 2020;382:1653-9.

75) Yuan W, Pan W, Kong J, et al. 1,25-Dihydroxyvitamin D3 Suppresses Renin Gene Transcription by Blocking the Activity of the Cyclic AMP Response Element in the Renin Gene Promoter. Journal of Biological Chemistry. 2007;282(41):29821-29830.

76) Sodhi CP, Wohlford-Lenane C, Yamaguchi Y, et al. Attenuation of pulmonary ACE2 activity impairs inactivation of des-Arg9 bradykinin/BKB1R axis and facilitates LPSinduced neutrophil infiltration. American Journal of Physiology-Lung Cellular and Molecular Physiology. 2018;314(1).

77) Watkins J. Preventing a covid-19 pandemic. Bmj. 2020:m810.
Ready to submit your research? Choose Auctores and benefit from:

$$
\begin{aligned}
& \text { * fast, convenient online submission } \\
& \text { rigorous peer review by experienced research in your field } \\
& \text { *apid publication on acceptance } \\
& \text { * authors retain copyrights } \\
& \text { * immediate DOI for all articles }
\end{aligned}
$$

At Auctores, research is always in progress.

Learn more https://www.auctoresonline.org/journals/internationaljournal-of-clinical-case-reports-and-reviews 